\title{
Relationship between $A B O$ blood groups and carcinoma of esophagus and cardia in Chaoshan inhabitants of China
}

\author{
Min Su ${ }^{1}$, Shan-Ming Lu ${ }^{1}$, Dong-Ping Tian ${ }^{1}$, Hu Zhao ${ }^{1}$, Xiao-YunLi' ${ }^{2}$, De-Rui Li ${ }^{3}$ and Zhi-Chao Zheng ${ }^{4}$
}

${ }^{1}$ Department of Pathology, ${ }^{2}$ Tumor Hospital, ${ }^{3,4}$ Second Teaching Hospital, Shantou University Medical College, Shantou 515031, China

Supported by the Key Teacher Fund, Ministry of Education of China and Sir Li Ka-Ching Foundation.

Correspondence to: Prof. Min Su, Department of Pathology, Shantou University Medical College, Shantou 515031,

China.minsu@ncrc.stu.edu.cn or minsusm@21cn.com

Telephone: +86-754-8900429, Fax: +86-754-8525667

Received 2001-05-31 Accepted 2001-07-18

\begin{abstract}
AIM To study the relationship between ABO blood groups and carcinoma of esophagus and cardia in Chaoshan inhabitants of China, which is a unique Littoral high-risk area of esophageal carcinoma in China. The poor communication and transportation in the past has made Chaoshan a relatively closed area and kept its culture and custure of old China thousand years ago.
\end{abstract}

METHODS Data on age, sex, ABO blood type and X-ray or patholog ical diagnose of the patients with carcinoma of esophagus or cardia were collected from the Tumor Hospital. First Affiliated Hospital, Second Affiliated Hospital of Shantou University Medical College; and the Central Hospital of Shantou and the Central Hospital of Jieyang. A total of 6685 patients with esophageal carcinoma (EC) and 2955 patients with cardiac cancer (CC) in Chaoshan district were retrospectively assessed for their association with ABO blood groups.

RESULTS The distribution of $\mathbf{A B O}$ blood groups in patients with EC or CC was similar to the normal local population in Chaoshan. However, blood group B in male patients with $\mathrm{CC}$ and in the patients with carcinoma in the upper third esophagus was $2.3 \%$ and $4.7 \%$ higher than the corresponding controls. The relative risk $B$ :O was $1.1415(P<0.05)$ and $1.2696(P<0.05)$, respectively. No relationship was found between ABO blood groups and tumor differentiation.

CONCLUSION ABO blood group B is associated with the incidence of $C C$ in male individuals and carcinoma in the upper third esophagus. The distri bution of ABO blood groups varies in the different geographical and ethnic groups. As a result, proper controls are very important for such studies.

Subject headings esophageal neoplasms; stomach neoplasms; ABO blood-group system; Guangdong; human

Su M, Lu SM, Tian DP, Zhao H, Li XY, Li DR, Zheng ZC. Relationship between $A B O$ blood groups and carcinoma of esophagus and cardia in Chaoshan inhabitants of China. World J Gastroenterol, 2001;7(5): 657-661

\section{INTRODUCTION}

Chaoshan is an enclosed littoral region surrounded by mountains located at the boundary between Guangdong Province and Fujian Province of China. Chaoshan residents mostly came from Henan, Shanxi, and Changan thousands years ago, and are a relatively isolated population with a high risk of esophageal carcinoma (EC) and cardiac carcinoma (CC). Within Chaoshan, the Nanao Island has the highest risk ${ }^{[1,2]}$. According to the report from the Department of Public Health. Guangdong Province in 1993, the mortalities of esophageal carcinoma in the Nana o Island were: $108.68 \pm 7.88 / 100000$ standardized population of China and 145.44 $\pm 10.49 / 100000$ standardized world population and 261.16 $\$ 25.01 / 100000$ standardized world population aged 35-64 years. The annual average incidence rates of male and female were 132.19/100 000 and 69.20/100 000 in the Nanao Island from 1987 to $1992^{[3,4]}$. It has been noticed that EC is a race-related disease. People of Chinese origin living in foreign countries have higher EC frequency than those of non-Chinese origin, and in comparison with the frequency in the people with Chaoshan origin is even higher. The mortality of EC within immigrants of the Nanao Island origin in Meixian County, Guangdong Province is 1.7 times that of the local residents ${ }^{[5]}$. The poor communication and transportation in the past has made Chaoshan a relatively closed society and formed its unique culture, customs and habits. A preliminary study showed that Chaoshan residents were migrants from central China, and their traditional culture, custom and habits were well kept. This unique society provides us an unparalleled base to study cultural and genetic factors and their interaction in the study of EC.

Since the association between blood group A and gastric cancer was reported in 1953, the relationship with blood groups and incidence ${ }^{[6-16]}$, clinicopathologic parameter ${ }^{[17,18]}$ and prognosis ${ }^{[19-21]}$ had been studied in many cancer and other disease ${ }^{[22,23]}$. However, there is no consistent result ${ }^{[24-27]}$. Additionally, ABO genes are distributed differently among socioeconomic groups ${ }^{[28]}$ and we know that socioeconomi c status is one of the risk factors for diseases. Thus, a retrospective assessment of the relation between blood groups and EC, CC was performed with a view to start the study of the genetics of these cancers in Chaoshan district.

\section{MATERIAL AND METHODS}

\section{Clinical data}

Data about age, sex, ABO blood type and X-ray or pathological diagnosis of the patients with EC and CC were collected from the Tumor Hospital (1978-1998). The First Affiliated Hospital (1989-1998), the Second Affiliated Hospital ( 1983 - 1998) of Shantou University Medical 
College; the Central Hospital of Shantou and the Central Hospital of Jieyang. A total of 6685 patients with EC and 2955 patients with $\mathrm{CC}$ in Chaoshan district were retrospectively assessed for the association with $\mathrm{ABO}$ blood groups. In these series, histopathological diagnoses were available in 4719 patients with EC and 2120 patients with CC. The differe ntiation of the carcinomas was categorized as grade 1 (welldifferentiated tumors) to grade 3 (poorly-differentiated tumors). The remaining cancers were diagnosed by X-ray. In 5638 patients with EC, there is definite information on tumor sites within the esophagus. All patients' medical records, including operative notes and histopathological reports, were reviewed.

\section{Normal control}

The $\mathrm{ABO}$ blood group distribution of the blood donors from the Central Blood Bank in Shantou city was used as control groups 7276 donors were sampled, of the same ethnic group and from the same native place as the patients.

\section{Statistical analysis}

Data were stored in a computer data base (FoxPro, version $2.5 \mathrm{~b}$ ) and analyzed using a computer spread sheet (Microsoft Excel 97) and professional statistical computer software (SPSS, version 6.12 and SAS, version 6.08). The differences of $\mathrm{ABO}$ blood group distribution in patient groups and controls were assessed using Chi-square test. The gene frequencies of blood group antigen were calculated by the method of Bernstein and the relative risks were estimated using Woolf's methods. $P$ values $<0.05$ were regarded as statistically significant.

\section{RESULTS}

The distribution of $\mathrm{ABO}$ blood groups in the EC group was similar to that of a normal population (Table 1) and so was the gene frequencies (Table 2). Although blood group B in total patients with $\mathrm{CC}$ and female patients with $\mathrm{CC}$ were $2.3 \%$ and $1.5 \%$ higher than the corresponding controls, the difference was not significant. In male patients with CC, there was a $1.6 \%$ deficiency of blood group A and a $2.3 \%$ excess of blood group $\mathrm{B}$ as compared with the male controls, and the two groups differ significantly in their $\mathrm{ABO}$ distribution $\left(\chi^{2}=8.518\right.$, $P<0.05)$. The gene frequencies of blood group B were 0.196 in male patients with $\mathrm{CC}$, which was higher than that of the male controls (0.175), and the relative risk B:O was $1.14(95 \%$ confidenc e interval 1.01-1.29) with statistical significance (Table 2). This suggests that male individuals with blood group $\mathrm{B}$ are more susceptible to $\mathrm{CC}$. With respect to the site of EC, carcinoma in the middle third esophagus is most common (73\%), but the prevalence of blood groups in this group and the lower third group were identical to the controls. The blood group B patients with carcinoma in the upper third esophagus was $4.7 \%$ higher than the controls, with a higher gene frequency $(0.2072)$, and the difference of the blood group distribution between the two groups was of statistical significance. When blood group $\mathrm{B}$ was compared with blood group $\mathrm{O}$, the relative risk was 1.27 (95\% confidence interval 1.05-1.54), which was statistically significant by Chi-square test. Although the prevalence of blood group B was a little lower in the poorly differentiated squamous cell carcinoma of the esophagus (ESCC) than expected, the deficiency did not reach significance. No relationship between the tumor differentiation and ABO blood group distribution was found.

Table 1 ABO blood group distribution in EC patients $(n, \%)$

\begin{tabular}{|c|c|c|c|c|c|c|}
\hline \multirow{2}{*}{ Groups } & \multirow{2}{*}{ Total } & \multicolumn{4}{|c|}{ Blood groups } & \multirow{2}{*}{$P$ value } \\
\hline & & $A(\%)$ & $\mathrm{AB}(\%)$ & $\mathrm{B}(\%)$ & $O(\%)$ & \\
\hline \multicolumn{7}{|l|}{ Control } \\
\hline Male & 5447 & $1468(27.0)$ & $345(6.3)$ & $1398(25.7)$ & $2236(41$. & \\
\hline Female & 1829 & $480(26.2)$ & $112(6.1)$ & $477(26.1)$ & $760(41.6)$ & \\
\hline Total & 7276 & $1948(26.8)$ & $457(6.3)$ & $1875(25.8)$ & $2996(41.1)$ & \\
\hline \multicolumn{7}{|l|}{ EC } \\
\hline Male & 4987 & $1336(26.8)$ & $271(6.0)$ & $1362(27.3)$ & $1990(39.9)$ & 0.260 \\
\hline Female & 1698 & $443(26.1)$ & $102(6.0)$ & $442(26.0)$ & $711(41.9)$ & 0.997 \\
\hline Total & 6685 & $1779(26.6)$ & $401(6.0)$ & $1804(27.0)$ & $2701(40.4)$ & 0.399 \\
\hline \multicolumn{7}{|l|}{$\mathrm{CC}$} \\
\hline Male & 2437 & $620(25.4)$ & $177(7.3)$ & $683(28.0)$ & $957(39.3)$ & $0.036^{n}$ \\
\hline Female & 518 & $138(26.7)$ & $27(5.2)$ & $143(27.6)$ & $210(40.5)$ & 0.790 \\
\hline Total & 2955 & $758(25.7)$ & $204(6.9)$ & $826(27,9)$ & $1167(39.5)$ & 0.057 \\
\hline \multicolumn{7}{|l|}{ Site of EC } \\
\hline Upper third & 673 & $164(24.4)$ & $46(6.8)$ & $205(30.5)$ & $258(38.3)$ & $0.045^{\mathrm{a}}$ \\
\hline Middle third & 4121 & $1126(27.3)$ & $243(5.9)$ & $1079(26.2)$ & $1673(40.6)$ & 0.725 \\
\hline Lower third & 844 & $206(24.4)$ & $51(6.1)$ & $245(29.0)$ & $342(40.5)$ & 0.186 \\
\hline \multicolumn{7}{|l|}{ Diff. (ESCC) } \\
\hline Well Diff. & 378 & $106(28.0)$ & $25(6.6)$ & $107(28.3)$ & $140(37.0)$ & 0.444 \\
\hline Moderately Diff. & 1290 & $340(26.4)$ & $75(5.8)$ & $334(25.9)$ & $541(41.9)$ & 0.893 \\
\hline Poorly Diff. & 572 & $160(28.0)$ & $20(3.5)$ & $152(26.6)$ & $240(41.9)$ & 0.064 \\
\hline \multicolumn{7}{|l|}{ Diff. (AC) } \\
\hline Well Diff. & 22 & $6(27.3)$ & $2(9.1)$ & $8(27.3)$ & $8(36.4)$ & 0.936 \\
\hline Moderately Diff. & 161 & $45(28.0)$ & $9(5.6)$ & $43(26.7)$ & $64(39.8)$ & 0.954 \\
\hline Poorly Diff. & 311 & $82(26.4)$ & $24(7.7)$ & $86(27.7)$ & $119(38.3)$ & 0.569 \\
\hline
\end{tabular}

${ }^{a} P<0.05$. EC: Esophagus cancer; CC: Cardiac cancer; AC: Adenocarcinoma;

ESCC: Squamous cell carcinoma in esophagus; Diff: Differentiation 
Table 2 Gene frequency of abo blood type in $\mathrm{EC}$ and $\mathrm{CC}$ patients

\begin{tabular}{|c|c|c|c|c|c|c|c|c|c|}
\hline \multirow{2}{*}{ Group } & \multicolumn{3}{|c|}{ Gene frequency } & \multicolumn{3}{|c|}{$\mathrm{AO}$} & \multicolumn{3}{|c|}{$\mathrm{B} / \mathrm{O}$} \\
\hline & $p$ & $q$ & $r$ & $\mathbf{R R}$ & $\mathrm{Cl}$ & $P$ & $\mathrm{RR}$ & $\mathrm{Cl}$ & $P$ \\
\hline Control & 0.1816 & 0.1754 & 0.6424 & & & & & & \\
\hline Total (EC) & 0,1758 & 0.1784 & 0.6405 & 1.01 & $0.93 \cdots 1.10$ & NS & 1.07 & $0.98-1.16$ & NS \\
\hline Upper (EC) & 0.1696 & 0.2072 & 0.6210 & 0.98 & $0.80-1.20$ & NS & 1.27 & $1.05-1.54$ & $<0.02$ \\
\hline Total $(c)$ & 0.1790 & 0.1925 & 0.6285 & 1.00 & $0.90 \cdots 1.11$ & NS & 1.13 & $1.02-1.26$ & NS \\
\hline Male $(C C)$ & 0.1794 & 0.1954 & 0.6252 & 0.99 & $0.88-1.11$ & NS & 1.14 & $1.01-1.29$ & $<0.03$ \\
\hline
\end{tabular}

$\mathrm{NS}$ : Not significant; CI: Confidence interval; $\mathrm{EC}$ : Esophageal cancer; $\mathrm{CC}$ : Cardiac cances

Table 3 Comparison of ABO blood group distribution in different districts in China

\begin{tabular}{|c|c|c|c|c|c|}
\hline \multirow{2}{*}{ Districts } & \multicolumn{4}{|c|}{ Blood groups } & \multirow{2}{*}{ Characteristics } \\
\hline & $\mathrm{A}(\%)$ & $\mathrm{AB}(\%)$ & $B\left(0_{0}\right)$ & $0(\%)$ & \\
\hline Linxian & $2936(24.5)$ & $1254(10.5)$ & $4279(35.6)$ & $3536(29.5)$ & $B>0>A>A B$ \\
\hline Shanxi & $2908(23.3)$ & $987(7.9)$ & $4120(33.0)$ & $4469(35.8)$ & $O>B>A>A B$ \\
\hline Dezhou & $994(28,4)$ & $318(9.1)$ & $1064(30.4)$ & $1124(32.1)$ & $O>A>B>A B$ \\
\hline Wuhan & $10799(33.2)$ & $2970(9.2)$ & $7180(21.9)$ & $11641(35.7)$ & $O>A>B>A B$ \\
\hline Hubei & $4461(32.5)$ & $1125(8.2)$ & $3376(24.6)$ & $4762(34.7)$ & $O>A>B>A B$ \\
\hline Lanzhou & $597(33.0)$ & $171(9.4)$ & $512(28.3)$ & $530(29.3)$ & $A>O>B>A B$ \\
\hline Yancheng & $947(30.3)$ & $299(9.6)$ & $845(27.0)$ & $1037(33.2)$ & $O>A>B>A B$ \\
\hline Chaoshan & $1948(26.8)$ & $457(6.3)$ & $1875(25.8)$ & $2996(41.2)$ & $O>A>B>A B$ \\
\hline
\end{tabular}

\section{DISCUSSION}

There seemed to be no association between $\mathrm{ABO}$ blood groups and the incidence of EC or CC when the studied patients were not grouped by sex and tumor site. This result is consistent with previous reports. However, in the present study, male individuals with blood group B were more susceptible to CC than those with other blood types, and blood group B was associated with carcinoma of the upper third of the esophagus. It suggested that the susceptibility of male to certain cancer was not the same as female. Thus, further classification by sex may be needed when studying the relation between ABO blood groups and cancer. No relation was found in the current study between blood groups and the histological differentiation of EC or CC. The relationship between ABO blood groups and carcinoma of esophagus and cardia has been controversial ${ }^{[29,30]}$. Mourant and his colleagues reported that blood groups A and B were both associated with EC and no relation was found between blood groups and $\mathrm{CC}$, based on the data from 31 districts in 13 countries and 7 districts of 6 countries, respectively ${ }^{[31]}$. But some authors have reported different associations according to geographical locations. Thus, blood group A was associated with EC in the British population of Belfast and blood group B individuals were susceptible to EC in British in Bristol, Bantu in South Africa and Iowa in America. But ABO blood groups have shown no correlation with EC in other districts in these countries ${ }^{[29]}$. These inconsistent results reflect two fundamental methodological problems with such association studies, the statistical methods and the selection of controls. Since the association between ABO blood groups and different cancers is not the same, associations may be observed if several kinds of carcinoma are analysed together. Small sample size is another possible inconsistency.

The importance of careful selection of controls is illustrated by the comparison of populations from different districts whthin China (Table 3). The distribution of ABO blood groups in different districts differs significantly $\left(\chi^{2}=\right.$ $0.141, P<0.01)$. For instance, there was a $10 \%$ excess of blood group A individuals in the population of Wuhan, compared with that of Shanxi, a $13.7 \%$ excess of blood group $\mathrm{B}$ individuals in Linxian compared with Wuhan, and a difference in the frequency of blood group $\mathrm{O}$ in Chaoshan compared to Shanxi, even though Chaoshan residents came from Henan, Shanxi, a thousand years or more ago. This suggests that the frequency of different alleles in immigrants to Chaoshan from Shanxi has drifted, compared with their originating population. The best control is, therefore, the ABO blood group distribution of the healthy population of the same ethnic group and sex and from the same native place as the patients $^{[32]}$. It is possible that blood group B is just a marker of the ancestral population from Shanxi which is now mixed into the Chaoshan region, Shanxi people are also the population at high risk of EC/CC.

The explanation for the association between ABO blood groups and some special diseases was still unclear. Many reports have shown that blood group antigen expression in tumor is correlated with metastasis ${ }^{[33,34]}$ and prognosis ${ }^{[35,36]}$. The loss or presence of blood group antigens can increase cellular motility or facilitate the interaction between tumor cells and the endothelium of distant organs ${ }^{[37,38]} \cdot \operatorname{ABO}(\mathrm{H})$ blood group genes are map at $9 q$ in which the genetic alteration is common in many cancers ${ }^{[39-44]}$. Thus, $\mathrm{ABO}(\mathrm{H})$ blood group antigen expression may be affected by the genetic change of tumors. On the other hand, it is possible that the observe $\mathrm{d}$ associations are not due to the blood group antigens themselves, but to the effects of genes closely associated with them. Additionally, it might have nothing to do with molecular mechanisms or genetics. It is merely the result of population history ${ }^{[45-47]}$, environment ${ }^{[45,48,49]}$, diet ${ }^{[50]}$ and customs ${ }^{[51-55]}$.

In conclusion, the current study shows no association of $\mathrm{ABO}$ blood groups with $\mathrm{EC}$ and $\mathrm{CC}$, when the patients are not separated by sex and tumor site. If they are so grouped, male individuals with blood group B are found to have increased risk for the development of CC, and blood group B individuals are more likely to get carcinoma in the upper third of the esophagus. These findings may contribute to the genetic or custom study of EC and CC.

ACKNOWLEDGEMENTS Prof. Bruce A J Ponder, CRC Departmen $t$ of Oncology, Cambridge Institute for Medical 
Research, for his critical review of the manuscript and his valuable suggestion. Ying Song-Min, Ni Yang, Gao Yu-Sen, Lin Jie, Sun Jun-Kai, Yuan Bi-Chai, Li Yi-Fan, Chen Xiao-Ling, Xu Jie-Song and Chen Ying-Fen for their arduous work in the investigation.

\section{REERENCES}

1 Li K, Su M, Yu P. Mortality trends for malignancies in Nanao county of Guangdong Province. Zhongguo Zhongliu, 2001;10:269-270

2 Chen WS, Cai SS, Lin Y, Ou LM, Zhong YS, Cai HY, Guo LM, Xu TQ, Yuan H, Zhang ZY. Mortality trends for malignancies in Jie Yang county of Guangdong Province from 1985 to 1987. Zhonghua Zhongliu Zazhi, 1992;14:469-470

3 Chen WS, Chen SR, Lin QH, Qiu JW, Xie XK, Fu LN, Li WM, Liao DD, Chen JH, Wu ZR, Qiu JM, Zhang HJ. Epidemiologic investigation of carcinoma of esophagus and gastric cardia carcinoma in Nanao county, Guangdong Province. Zhonghua Zhongliu Zazhi, 1986;8:265267

4 Chen WS, Yang HL, Cai SS, Qiu JW, Zhang C, Lin K. Epidemiologic features of e sophagus cancer in Na'nao County, Guangdong Province from 1987 to 1992. Aizheng, 1996;15:274-276

5 Tang ZY. Modern Oncology. First Edition. Shanghai: Shanghai Medical University Publications Ltd, 1993:455-456

6 You WC, Ma JL, Liu W, Gail MH, Chang YS, Zhang L, Hu YP, Fraumeni JF, Xu GW. Blood type and family cancer history in relation to precancerous gastric lesions. Int J Epidemiol, 2000;29:405-407

7 Pyd M, Rzewnicki I, Suwayach U. Grupy krwi ukladu abouchorych zrakiem krtanii gardla dolnego. ABO blood groups in patients with laryngeal and hypopha ryngeal cancer. Otolaryngol Pol, 1995;49 (Suppl):20396-20398

8 Hallstone AE, Perez EA. Blood type and the risk of gastric disease. Science, 1994;264:1386-1388

9 Vioque J, Walker AM. Cancer de pancreasy tipologia sanguinea ABO: un estudio decasosy controles. Pancreatic cancer and ABO blood types: a study of cases and controls. Med Clin (Barc), 1991;96: 761-764

10 Asano A, Mizuno S, Sasaki R, Aoki K. Family study of cancer among gastrectomized patients. Gan No Rinsho, 1987;33(Suppl 5):463-468

11 Sasaki K, Hata H, Nakano R. ABO blood group in patients with malignant trophoblastic disease. Gynecol Obstet Invest, 1985;20:23-26

12 Parazzini F, La Vecchia C, Franceschi S, Pampallona S, Decarli A, Mangili G, Belloni C. ABO blood-groups and the risk of gestational trophoblastic disease. Tumori, 1985;71:123-126

13 Grimes DA. Epidemiology of gestational trophoblastic disease. Am J Obstet Gynecol, 1984;150:309-318

14 Nishi M, Takao S, Aiko T. Clinical and genetic study on human cancer-gastric cancer. Gan To Kagaku Ryoho, 1982;9:790-798

15 Anderson DE, Haas C. Blood type A and familial breast cancer. Cancer, 1984;54:1845-1849

16 Langer M, Gitsch E, Salzer H. Die Bedeutung des ovulatorischen Alters beider Entstehung des Ovarialkarzinoms. Significance of ovulatory age in the pathogenesis of ovarian cancer. Geburtshilfe Frauenheilkd, 1984;44:366-367

17 Slater G, Itzkowitz S, Azar S, Aufses AH. Clinicopathologic correlatio ns of $\mathrm{ABO}$ and Rhesus blood type in colorectal cancer. Dis Colon Rectum, 1993;36:5-7

18 Kvist E, Lauritzen AF, Bredesen J, Luke M. Relationship between blood groups and tumors of the upper urinary tract. Scand J Urol Nephrol, 1988;22:289-291

19 Marinaccio M, Traversa A, Carioggia E, Valentino L, Coviello M, Salama nna S, Dragone DC, Marinaccio L. Gruppi sanguigni del sistema $\mathrm{ABO}$ esopravvivenz a neitumori ginecologici. Blood groups of the $\mathrm{ABO}$ system and survival rate in gynecologic tumors. Minerva Ginecol, 1995;47:69-76

20 Nguyen PL, Swanson PE, Jaszcz W, Aeppli DM, Zhang G, Singleton TP, War d S, Dykoski D, Harvey J, Niehans GA. Expression of epidermal growth factor receptor in invasive transitional cell carcinoma of the urinary bladder. A multivariate survival analysis. Am J Clin Pathol, 1994;101:166-176

21 Holdsworth PJ, Thorogood J, Benson EA, Clayden AD. Blood group as a prognostic indicator in breast cancer. Br Med J (Clin Res Ed), 1985; 290:671-673

22 Lorigan PC, Sharma S, Bright N, Coleman RE, Hancock BW. Characteristic s of women with recurrent molar pregnancies. Gynecol Oncol, 2000;78(3 Pt 1): 288-292
23 Zhou P, Cui X, Li XY, Li YS. The clinical significant of ABO blood group system distribution in patients with liver cirrhosis. Shijie Huaren Xiaohua Zazhi, 2000;8:715

24 Lissowska J, Groves FD, Sobin LH, Fraumeni JF, NasierowskaGuttmejer A, Radziszewski J, Regula J, Hsing AW, Zatonski W, Blot WJ, Chow WH. Family history and risk of stomach cancer in Warsaw, Poland. Eur J Cancer Prev, 1999;8:223-227

25 Pinkston JA, Cole P. ABO blood groups and salivary gland tumors (Alabama, United States). Cancer Causes Control, 1996;7:572-574

26 Nowinska E, Namyslowski G, Scierski W, Kocierz S. Rozklad grup krwi ABO uchorych zrakiem krtani. ABO blood groups in the patients with laryngeal cancer. Otolaryngol Pol, 2000;54(Suppl):3120931211

27 Mehdi SA, Tatum AH, Newman NB, Imperato A, Daucher J, Kohman LJ, Grazi ano SL. Prognostic significance of Lewisy antigen in resected stage I and II non-small cell lung cancer. Chest, 1998;114:1309-1315

28 Beardmore JA, Karimi-Booshehri F. ABO genes are differentially distributed in socio-economic groups in England. Nature, 1983;303: 522-524

29 Wu M, Wang XQ, Zhu QL, Shao LF. Distribution of ABO blood groups among patients with carcinoma of esophagus and gastric cardia in Linxian people Hospital. Zhonghua Zhongliu Zazhi, 1981;3: 16-18

30 Wan DS, Li GC, Zhang YQ, Zeng CG, Zhu ZZ, Huang LX. Malignant tumors and ABO blood groups- an analysis of 10258 patients with malignant tumors. Zhonghua Zhongliu Zazhi, 1984;6:435-437

31 Mourant AE, Kopec AC, Domaniewska-Sob-zak. Blood group and disease. Oxford: Oxford University Press, London, 1978

32 Petrakis NL, King MC. Genetic markers and cancer epidemiology. Cancer, 1977;39(Suppl 4):1861-1866

33 Sleeman JP, Kim U, LePendu J, Howells N, Coquerelle T, Ponta H, Herrli ch P. Inhibition of MT-450 rat mammary tumour growth by antibodies recognising subtypes of blood group antigen B. Oncogene, 1999;18:4485-4494

34 Quan X, Luo HS. Blood group H antigen and gastrointestinal newplasma. Xin Xiaohuabingxue Zazhi, 1997;5:185-186ª

35 Nakagoe T, Nanashima A, Sawai T, Tuji T, Ohbatake M, Jibiki M, Yamaguc hi H, Yasutake T, Ayabe H, Matuo T, Tagawa Y. Expression of blood group antigens $\mathrm{A}, \mathrm{B}$ and $\mathrm{H}$ in carcinoma tissue correlates with a poor prognosis for colorectal cancer patients. J Cancer Res Clin Oncol, 2000;126:375-382

36 Moldvay J, Scheid P, Wild P, Nabil K, Siat J, Borrelly J, Marie B, Farre G, Labib T, Pottier G, Sesboue R, Bronner C, Vignaud JM, Martinet $\mathrm{Y}$, Martine t N. Predictive survival markers in patients with surgically resected non-small cell lung carcinoma. Clin Cancer Res, 2000;6: 1125-1134

37 Le Pendu J, Marionneau S, Cailleau Thomas A, Rocher J, Le Moullac Vaidey $\mathrm{B}, \mathrm{Clement} \mathrm{M}$. ABH and lewis histo-blood group antigens in cancer. APMIS, 2001;109:9-31

38 Ichikawa D, Handa K, Hakomori S. Histo-blood group A/B antigen deletion/reduction $v s$. continuous expression in human tumor cells as correlated with their malignancy. Int J Cancer, 1998;76:284-289

39 Hu N, Roth MJ, Polymeropolous M, Tang ZZ, Emmert Buck MR, Wang QH, Gol dstein AM, Feng SS, Dawsey SM, Ding T, Zhang ZP, Han XY, Ried T, Giffen C, Taylor PR. Identification of novel regions of allelic loss from a genomewide scan of esophageal squamous-cell carcinoma in a high-risk Chinese population. Genes Chromosomes Cancer, 2000;27:217-228

40 Pack SD, Karkera JD, Zhuang Z, Pak ED, Balan KV, Hwu P, Park WS, Pham T, Ault DO, Glaser M, Liotta L, Detera Wadleigh SD, Wadleigh RG. Molecular cytogenetic fingerprinting of esophageal squamous cell carcinoma by comparative genomic hybridization reveals a consistent pattern of chromosomal alterations. Genes Chromosomes Cancer, 1999;25:160-168

41 Simoneau M, LaRue H, Aboulkassim TO, Meyer F, Moore L, Fradet Y. Chromosome 9 deletions and recurrence of superficial bladder cancer: identification of four regions of prognostic interest. Oncogene, 2000;19:6317-6323

42 Zitzelsberger H, Engert D, Walch A, Kulka U, Aubele M, Hofler H, Bauchinger M, Werner M. Chromosomal changes during development and progression of prostate adenocarcinomas. Br J Cancer, 2001; 84:202-208

43 Sirivatanauksorn V, Sirivatanauksorn Y, Gorman PA, Davidson JM, Sheer D, Moore PS, Scarpa A, Edwards PA, Lemoine NR. Nonrandom chromosomal rearrang ements in pancreatic cancer cell lines identified by spectral karyotyping. Int J Cancer, 2001;91:350-358 
44 Singh B, Lim D, Cigudosa JC, Ghossein R, Shaha AR, Poluri A, Wreesmann VB, Tuttle M, Shah JP, Rao PH. Screening for genetic aberrations in papillary thyroid cancer by using comparative genomic hybridization. Surgery, 2000;128:888-893

45 Phillips R, Mawhinney T, Harmata M, Smith D. Characterization of Gall us domesticus alpha-N-acetyl-galactosaminidase blood group A2 activity. Artif Cells Blood Substit Immobil Biotechnol, 1995;23:63-79

46 Henry SM, Oriol R, Samuelsson BE. Detection and characterization of Lewis antigens in plasma of Lewis-negative individuals. Evidence of chain extension as a result of reduced fucosyltransferase competition. Vox Sang, 1994;67:387-396

47 Chen CY, Lu CL, Lee PC, Wang SS, Chang FY, Lee SD. The risk factors for gallstone disease among senior citizens: an oriental study. Hepatogastroen terology, 1999;46:1607-1612

48 Rosendale JD, McBride MA. Organ donation in the United States: 1990-1998. Clin Transpl, 1999:83-94

49 Langston MM, Procter JL, Cipolone KM, Stroncek DF. Evaluation of the gel system for ABO grouping and D typing. Transfusion, 1999;39: 300-305

50 Moen T. "Blood type diet"- science or fantasy Tidsskr Nor Laegeforen, 2001;121:355-358

51 Wolfe RA, Ashby VB, Milford EL, Bloembergen WE, Agodoa LY, Held PJ, Port FK. Differences in access to cadaveric renal transplantation in the United States. Am I Kidney Dis, 2000;36:1025-1033

52 Datta UK, Mondal S, Mukherjee S. A study of the distribution of ABO and $\mathrm{Rh}(\mathrm{D})$ blood groups amongst Lodha tribe in Midnapore district of West Bengal. J Indian Med Assoc, 1997;95:497-498,506

53 Drasin T, Sahud M. Blood-type and age affect human plasma levels of histidine-rich glycoprotein in a large population. Thromb Res, 1996; 84:179-188

54 Feizi T, Wallace P, Haines AP, Peters TJ. Blood groups, secretor status and salivary Lewis. Lewis and 19.9 antigen levels in alcoholics and ethnic origin-matched controls. Alcohol Alcohol, 1991;26:535-539

55 Dudin AA, Rambaud-Cousson A, Badawi S, Da'na NA, Thalji A, Hannoun $\mathrm{A}$. $\mathrm{ABO}$ and $\mathrm{Rh}(\mathrm{D})$ blood group distribution and their implication for feto-maternal incompatibility among the Palestinian population. Ann Trop Paediatr, 1993;13:249-252

56 Wang LD, Yang WC, Zhou Q, Xing Y, Jia YY, Zhao X. Changes of p53 and Waf1p21 and cell proliferation in esophageal carcinogenesis. China Natl J New Gastroenterol, 1997;3:87-89a a

57 Wang LD, Zhou Q, Zhang YC, Li XF, Wang WP, He L, Gao SS, Li $Y X$. p53 alterations and cell proliferation in esophageal epithelia among subjects from high and low incidence areas of esophageal cancer. Xin Xiaohuabingxue Zazhi, 1997;5:221-222

58 Zou JX, Chen YL, Wang ZH, Wang LD, Zhou Q, Zhao X. Correlation between alteration of tumor suppressor gene p53, p16 and biological behavior of gastric cancer. Xin Xiaohuabingxue Zazhi, 1997;5:775-776

59 Zhou Q, Wang LD, Gao SS, Li YX, Zhao X, Wang LX. p53 immunostaining positive cells correlated positively with $\mathrm{S}$ phase cells as measured by BrdU in the esophageal precancerous lesions from the subjects at high incidence area for esophageal cancer in northern China. World J Gastroenterol, 1998;4(Suppl 2):106-107

60 Wang LD. Morphologic changes and molecular basic research of multiste p esophageal carcinogenic process. Xin Xiaohuabingxue Zazhi, 1996;5(Suppl 6):15-16

61 Zou JX, Wang LD, Shi-Stephanie T, Yang GY, Xue ZH, Gao SS, Li YX, Yang CS. p53 gene mutations in multifocal esophageal precancerous and cancerous lesions in patients with esophageal cancer in highrisk northern China. Shijie Huaren Xiaohua Zazhi, 1999;7:280-284

62 Wang LD, Zhou Q, Zhang YC, Li XF, Wang WP, He L, Gao SS, Li YX. P53 al terations and cell proliferation in esophageal epithelia among subjects from high and low incidence areas of esophageal cancer. China Natl J New Gastroenterol, 1997;3:80

63 Wang LD, Zhou Q, Wei JP, Yang WC, Zhao X, Wang LX, Zou JX, Gao SS, Li YX, Yang CS. Apoptosis and its relationship with cell proliferation, p53, Waf1p2 1, bcl-2 and c-myc in esophageal carcinogenesis studied with a high-risk population in northern China. World J Gastroenterol, 1998;4:287-293

64 Liu J, Su Q, Zhang W. Relationship between HPV-E6 P53 protein and esophageal squamous cell carcinoma. Shijie Huaren Xiaohua Zazhi, 2000;8:494-496

65 Wang DX, Li W. Advanced on pathogenesis of esophageal cancer. Shijie Huaren Xiaohua Zazhi, 2000;8:1029-1030

66 Zhou Q, Zou JX, Chen YL, Yu HZ, Wang LD, Li YX, Guo HQ, Gao SS, Qiu SL. Alteration of tumor suppressor gene $\mathrm{p} 16$ and $\mathrm{Rb}$ in gastric cancinogesis. China Natl J New Gastroenterol, 1997;3:262

Edited by Ma JY 